\title{
Effect of Ethephon Application on Seed Yield and Yield Components of Two Faba Bean (Vicia faba L.) Cultivars
}

\begin{tabular}{|c|c|}
\hline \multicolumn{2}{|c|}{$\begin{array}{l}\text { IDepartment of Field Crops, Faculty of Agricultural, University of Cukurova, } 01330 \text { Adana, Turkey } \\
{ }^{*} \text { Corresponding author }\end{array}$} \\
\hline A R T I C L E I N F O & A B S T R A C T \\
\hline $\begin{array}{l}\text { \#This study was presented as an online } \\
\text { presentation at the } 2^{\text {nd }} \text { International } \\
\text { Journal of Agriculture-Food Science } \\
\text { and Technology (TURJAF 2021) } \\
\text { Gazimağusa Cyprus and developed } \\
\text { from the paper published in the } \\
\text { congress book. } \\
\text { Research Article } \\
\text { Received : 07/11/2021 } \\
\text { Accepted : 24/11/2021 } \\
\text { Keywords: } \\
\text { Faba bean } \\
\text { Cultivar } \\
\text { Ethephon application } \\
\text { Seed yield } \\
\text { Growth regulator }\end{array}$ & $\begin{array}{l}\text { The aim of present study was to determine the effects of different ethephon doses on grain yield } \\
\text { and yield components of two faba bean cultivars. The experiment was established in } 2019 / 2020 \text { and } \\
2020 / 2021 \text { cropping season at Research Area of Field Crops Department, Agriculture of Faculty, } \\
\text { Cukurova University Adana, Turkey. The field experiment was laid out in randomized complete } \\
\text { blocks design (RCBD) with three replications on the basis split plot design with cultivars (Luz de } \\
\text { Otono and Histal) in main plots and ethephon doses }\left(0,500,1000,1500 \mathrm{~g} \mathrm{ha}^{-1} \text { ) in sub plots. Plant }\right. \\
\text { height }(\mathrm{cm}) \text {, branches per plant, pods per plant, seeds per plant, seed yield per plant (g), } 100 \text { grain } \\
\left.\text { weight }(\mathrm{g}) \text {, seed yield ( } \mathrm{kg} \mathrm{ha}^{-1}\right) \text { were investigated. Differences among the cultivars and ethephon } \\
\text { applications were significant for seed yield and it varied from } 1782 \text { to } 3388 \mathrm{~kg}^{-1} \text { in the mean of } \\
\text { the years. Seed yield also decreased with increasing ethephon doses. Seed yield was higher in } \\
\left.\text { 2019/2020 (3355 kg ha) than } 2020 / 2021 \text { ( } 1841 \mathrm{~kg} \mathrm{ha}^{-1}\right) \text { where low rainfed and high temperature. } \\
\text { The present results suggested that ethephon applications at inititation of flowering were not useful } \\
\text { for seed production of faba bean. }\end{array}$ \\
\hline
\end{tabular}

\section{Introduction}

Faba bean (Vicia faba L.) is used as animal feed in addition to human nutrition. Faba bean has an important role in agricultural production and it is a beneficial food crop in terms of high protein content and quality (Sheelamary and Shivani, 2015). At the same time, faba bean is need to low input in the cropping systems. It fixed the nitrogen from the air through the Rhizobum symbiotically. Faba bean can be grown as a winter crop in coastal regions under rainfed conditions for grain production (Ton et al., 2021). In this regions plant height may be increasing in the excessive rainy years, so seed maturity is late and harvest can be difficult due to lodging. So, low seed yield is one of the most problems for producers. Plant bio regulators are natural or synhetic compounds and they also have importance for increasing yield and quality of legume crops (Kumar, 2021). The studies relation to ethephon application on seed production of some crops are wide, but there are very limited studies for using growth retard in legumes. Plant growth regulators provided increasing seed yield in pulses and use of various growth regulators positively affected crop growth rate and assimilation rate in chickpea (Verma et al., 2018). The applications of ethephon and other growth regulators on various crops were reported by some studies. Ethephon is a synthetic growth retarding chemical and it reduces plant height in sunflower and maize (Spitzer, 2011; Spitzer et al., 2015) and chickpea (Güler et al., 2009). Ethilen regulates flowering, so provides early and same time maturity in plants (Kumlay and Eryiğit, 2011). The effect of plant growth regulators is important in early application timing than late applications in faba bean (Walela et al., 2016). Bora and Sarma (2006) reported that gibberellic acid (GA3) and cycocel can increase seed yield and protein content in seed of pea. The highest yield was obtained from 500 and $750 \mathrm{ppm}$ doses of cycocel applied in three-leaves stage of faba bean, but grain yield was not increasing yield due to cycocel application in pod setting of faba bean (Beşer and Adak, 1999). Ethephon can be used to benefit for early maturity of crops. Ngatia et al. (2003) recorded that ethephon application did not positively affect bean production. Flowering time is very important for legumes and early or late flowering depend on weather conditions. 
Ethephon delayed flowering time and reduced plant height in several herbaceous perennials (Hayashi et al., 2001). Spitzer et al. (2011) reported that growth regulators delayed in flowering onset of sunflower. Paclobutrazol reduced stem height, so increased seed yield and yield components in field bean (Vicia faba), but paclobutrazol and triapenthenol did not affect seed yield in lens (Field and et al., 1989). Effendi et al. (1989) indicated that effect of paclobutrazol and triapenthenol on seed yield is not significant, but these plant growth regulators reduced plant height and mean internode length in lentil.

The present study was carried out to determine the effects of applications for different ethephon doses on seed yield and yield components of two faba bean cultivars.

\section{Material and Methods}

\section{Climate and Soil Characters of Experiment Site}

The experiment was established in 2019/2020 and 2020/2021 cropping season at the Research Area of Field Crops Department (3702'18.06 N, 35² 22'39.93'E and 73 $\mathrm{m}$ above sea level), Faculty of Agriculture, University of Cukurova, Adana, Turkey. The soil type of experimental site was loam in textures. The other soil characters are salt content, value of $\mathrm{pH}$, available phosphour content, organic matter were 0.275 milimhos $\mathrm{cm}^{-1}$ and $8.2,3.3 \mathrm{~kg} \mathrm{da}^{-1}, 2.3 \%$ respectively.

Values of monthly average temperature and total precipation of area are given in Table 1.

\section{Plant Material}

Two commericial cultivars (Luz de otono and Histal) were used as the plant material in the study. Luz de otono is early cultivar, while Histal is late cultivar.

\section{Methods}

Experiment Design and Cultural Practices

The field experiment was laid out in randomized complate blocks design (RCBD) with three replications on the basis split plot design with cultivars in main plots and ethephon doses in sub plots. Different ethephon (480 g/lt) doses $(0,500,1000,1500 \mathrm{~g} / \mathrm{ha})$ were applied at the flowering initiation.

The sowings were made in 13 November 2019 and 18 November 2020. Experimental plots consists of 4 rows with row to row distance of $45 \mathrm{~cm}$ and plant to plant distance of $10 \mathrm{~cm}$. The plot area was $7.2 \mathrm{~m}^{2}(4.0 \mathrm{~m} \times 1.8$ m). Harvest was made in the middle two rows after eliminating the border rows. Fertilizer was applied at rate $30 \mathrm{~kg} \mathrm{ha}^{-1} \mathrm{~N}$ and $80 \mathrm{~kg} \mathrm{ha}^{-1} \mathrm{P}_{2} \mathrm{O}_{5}$ before sowing. Field emergences were recorded on 17 December 2019 and on 15 December 2020. Maturing date was recorded on the $8^{\text {th }}$ of May for Luz de otono and on the $19^{\text {th }}$ of May for Histal in 2020 while it was recorded on the $29^{\text {th }}$ of April for Luz de otono and on the $11^{\text {th }}$ of May for Histal in 2021.

\section{Observations}

Data were recorded from five randomly selected plant of each plot. Plant height $(\mathrm{cm})$, first podding height $(\mathrm{cm})$, primary branches per plant, pods per plant, seeds per plant, seed weight per plant $(\mathrm{g}), 100$-seed weight $(\mathrm{g})$, seed yield $\left(\mathrm{kg} \mathrm{ha}^{-1}\right)$ were observed.

\section{Statistical Analysis}

The data for morphological traits were analysed according to the split plot experiment design for every year seperately and combined year by using the MSTAT-C a computer software package. Comparisons among the means were using LSD multiple range test at 0.05 probability level.

\section{Results and Discussion}

The effects of cultivars and ethephon applications on plant height, first podding height and branches per plant of faba bean is presented in Table 2 .

Differences among the cultivars were significant for plant height in both of the years and the combined years (Table 2). There were not significant differences among the years for this trait. Later maturing variety Histal has higher plant height $(63.7 \mathrm{~cm})$ as compared to early maturing Luz de Otona (46.1) in the mean of the years. Previous studies showed that plant height varied between $85.5-115.2 \mathrm{~cm}$ (Musallam et al. 2004) and 80.07- $100.63 \mathrm{~cm}$ (Pekşen et al. 2006) according to cultivars and environmental conditions. There were significant differences among the ethephon doses for plant height in the first year and the mean of experimental years. Plant height in the second year where low rainfed and high temperature in vegetative stage of crop was not influenced by ethephon doses. As the mean of years, the highest plant height was achieved by control application $\left(0 \mathrm{~g} \mathrm{ha}^{-1}\right)$ with $61.5 \mathrm{~cm}$ followed by $500 \mathrm{~g} \mathrm{ha}^{-1}$ doses of ethephon with $56.2 \mathrm{~cm}$ whereas the lowest value was obtained from $1500 \mathrm{~g} \mathrm{ha}^{-1}$ with $49.5 \mathrm{~cm}$.

Table 1 . Values of monthly average temperature and total rainfall of experiment area

\begin{tabular}{|c|c|c|c|c|c|c|c|c|c|c|}
\hline \multirow[t]{3}{*}{ Months } & \multicolumn{2}{|c|}{$\begin{array}{c}\text { Min } \\
\text { Temperature } \\
\left({ }^{\circ} \mathrm{C}\right) \\
\end{array}$} & \multicolumn{2}{|c|}{$\begin{array}{c}\text { Max } \\
\text { Temperature } \\
\left({ }^{\circ} \mathrm{C}\right) \\
\end{array}$} & \multirow{2}{*}{\multicolumn{2}{|c|}{$\begin{array}{c}\text { Mean } \\
\text { Temperature } \\
\left({ }^{\circ} \mathrm{C}\right)\end{array}$}} & \multicolumn{2}{|c|}{$\begin{array}{c}\text { Relatively } \\
\text { Humidity } \\
(\%)\end{array}$} & \multicolumn{2}{|c|}{$\begin{array}{l}\text { Total Rainfall } \\
\quad(\mathrm{mm})\end{array}$} \\
\hline & & & & & & & & & & \\
\hline & $\mathrm{A}$ & B & $\mathrm{A}$ & B & $\mathrm{A}$ & $\mathrm{B}$ & A & B & $\mathrm{A}$ & B \\
\hline November & 10.3 & 7.1 & 30.6 & 27.8 & 18.1 & 17.0 & 56.7 & 59.5 & 22.6 & 52.6 \\
\hline December & 6.5 & 4.2 & 20.7 & 22.7 & 12.2 & 13.4 & 79.4 & 63.9 & 414.0 & 31.0 \\
\hline January & 0.6 & -0.1 & 18.0 & 22.9 & 9.9 & 11.7 & 67.9 & 63.7 & 140.2 & 131.4 \\
\hline February & -2.1 & 2.4 & 22.8 & 24.3 & 10.4 & 13.1 & 67.1 & 61.4 & 93.0 & 23.9 \\
\hline March & 5.8 & 3.1 & 27.6 & 34.4 & 15.3 & 13.9 & 69.3 & 68.7 & 47.4 & 45.7 \\
\hline April & 8.3 & 6.6 & 29.9 & 34.0 & 18.3 & 18.3 & 70.2 & 64.9 & 21.4 & 44.0 \\
\hline May & 12.9 & 14.9 & 40.3 & 30.7 & 23.3 & 23.9 & 61.0 & 64.9 & 66.6 & 4.1 \\
\hline
\end{tabular}


Table 2. The effects of cultivars and ethephon applications on plant height, first podding height and branches per plant in faba bean

\begin{tabular}{|c|c|c|c|c|c|c|c|c|c|}
\hline \multirow{2}{*}{ Treatments } & \multicolumn{3}{|c|}{ Plant Height $(\mathrm{cm})$} & \multicolumn{3}{|c|}{ First Podding Height $(\mathrm{cm})$} & \multicolumn{3}{|c|}{ Main Branches/Plant } \\
\hline & $2019 / 20$ & $2020 / 21$ & Mean & $2019 / 20$ & $2020 / 21$ & Mean & $2019 / 20$ & $2020 / 21$ & Mean \\
\hline \multicolumn{10}{|c|}{ Cultivar } \\
\hline Luz de otono & $46.7^{\mathrm{b}}$ & $45.6^{\mathrm{b}}$ & $46.1^{\mathrm{b}}$ & 14.4 & $16.2^{\mathrm{b}}$ & $15.4^{\mathrm{b}}$ & 2.58 & 3.46 & 3.02 \\
\hline Histal & $66.1^{\mathrm{a}}$ & $61.3^{\mathrm{a}}$ & $63.7^{\mathrm{a}}$ & 19.7 & $20.9^{\mathrm{a}}$ & $20.3^{\mathrm{a}}$ & 2.71 & 3.47 & 3.09 \\
\hline p.(cultivar) & $0.0162^{*}$ & $0.0224^{*}$ & $0.0005^{* *}$ & N.S & $0.0024^{* *}$ & $0.0023^{* *}$ & N.S. & N.S. & N.S. \\
\hline \multicolumn{10}{|c|}{ Doses $\left(\mathrm{g} \mathrm{ha}^{-1}\right)$} \\
\hline 0 & $65.8^{\mathrm{a}}$ & 57.3 & $61.5^{\mathrm{a}}$ & $20.5^{\mathrm{a}}$ & $25.5^{\mathrm{a}}$ & $23.0^{\mathrm{a}}$ & 2.60 & $2.25^{\mathrm{c}}$ & $2.43^{\mathrm{c}}$ \\
\hline 500 & $58.6^{\mathrm{ab}}$ & 53.7 & $56.2^{\mathrm{b}}$ & $17.4^{\mathrm{ab}}$ & $21.2^{\mathrm{b}}$ & $19.3^{\mathrm{b}}$ & 2.70 & $3.27^{\mathrm{b}}$ & $2.98^{\mathrm{b}}$ \\
\hline 1000 & $52.7^{\mathrm{bc}}$ & 52.6 & $52.7^{\mathrm{bc}}$ & $15.3^{\mathrm{b}}$ & $14.6^{\mathrm{c}}$ & $14.9^{\mathrm{c}}$ & 2.67 & $4.13^{\mathrm{a}}$ & $3.40^{\mathrm{ab}}$ \\
\hline 1500 & $48.6^{\mathrm{c}}$ & 50.4 & $49.5^{\mathrm{c}}$ & $15.0^{\mathrm{b}}$ & $13.1^{\mathrm{c}}$ & $14.1^{\mathrm{c}}$ & 2.63 & $4.20^{\mathrm{a}}$ & $3.42^{\mathrm{a}}$ \\
\hline LSD $\% 5$ & 7.31 & N.S. & 4.30 & 3.60 & 3.51 & 2.38 & N.S. & 0.73 & 0.42 \\
\hline Mean & 56.4 & 53.5 & 55.0 & 17.1 & 18.6 & 17.8 & $2.65^{\mathrm{b}}$ & $3.46^{\mathrm{a}}$ & 3.05 \\
\hline p.(year) & & & N.S. & & & N.S. & & & $0.0014^{* * *}$ \\
\hline $\mathrm{CV} \%$ & 10.3 & 7.99 & 9.27 & 16.8 & 15.0 & 15.8 & 15.5 & 16.7 & 16.5 \\
\hline
\end{tabular}

Table 3. Interaction of cultivars and ethephon doses for faba bean in combined years

\begin{tabular}{l|cccc}
\hline \multirow{2}{*}{ Doses $\left(\mathrm{g} \mathrm{ha}^{-1}\right)$} & \multicolumn{3}{c}{ Cultivar } \\
\cline { 2 - 5 } & \multicolumn{2}{|c}{ First podding height $(\mathrm{cm})$} & Branches/plant \\
& Luz de otono & Histal & Luz de otono & Histal \\
\hline 0 & $20.58^{\mathrm{bc}}$ & $25.40^{\mathrm{a}}$ & $2.65^{\mathrm{cd}}$ & $2.20^{\mathrm{d}}$ \\
500 & $14.30^{\mathrm{d}}$ & $24.27^{\mathrm{ab}}$ & $3.13^{\mathrm{bc}}$ & $2.83^{\mathrm{c}}$ \\
1000 & $13.40^{\mathrm{d}}$ & $16.43^{\mathrm{cd}}$ & $3.07^{\mathrm{bc}}$ & $3.73^{\mathrm{a}}$ \\
1500 & $13.13^{\mathrm{d}}$ & $14.97^{\mathrm{d}}$ & $3.23^{\mathrm{ac}}$ & $3.60^{\mathrm{ab}}$ \\
\hline LSD 5\% & & & & 0.60 \\
\hline
\end{tabular}

$\mathrm{P} \leq 0.05^{*} ; \mathrm{P} \leq 0.01^{*}$

Walela et al. (2016) recorded that various plant growth retards reduced plant height and it varied between 34-53 $\mathrm{cm}$ in faba bean. Previous studies have explained a more significant effect of PGRs in reducing vegetative growth or plant height in faba bean (El- Betagy et al, 1976; Field et al., 1989), lentil (Effendi, 1989) and bean (Ngatia, 2003). However, Turk et al. (2003) recorded that plant height was not affected by ethephon applications in lentil. Application timing can be shown different effects for plant height in faba bean and various legumes. Thus, Walela et al. (2016) noted that plant height reduced by PGRs applications in faba bean and effective of its in early growth stage is more than later applications pre flowering in faba bean.

Differences among the cultivars were not significant for first podding height in the first year (Table 2). First podding height of late maturing Histal $(20.9 \mathrm{~cm})$ in the second year was significantly higher than early maturing Luz de otono $(16.2 \mathrm{~cm})$. First podding height was significantly influenced by ethephon applications in both of the years and combined years. Increasing ethephon doses reduced the first podding height. Hence, In the first year differences between the 0 and $500 \mathrm{~g} \mathrm{ha}^{-1}$ ethephon applications were not significant for this trait. As the average of the years, the first podding height varied from $14.1\left(1500 \mathrm{~g} \mathrm{ha}^{-1}\right)$ to $23.0 \mathrm{~cm}\left(0 \mathrm{~g} \mathrm{ha}^{-1}\right)$. Sözen and Karadavut (2016) recorded that first pod height was between $23.0-30.0 \mathrm{~cm}$. This findings showed that first podding height varied according to ecological conditions, genotypes and growing techniques. The first podding height was not affected by years as in plant height. Statistical analysis exhibited a significant of cultivar $x$ ethephon doses interaction for first podding height in the mean of years (Table 3).

First podding height of early flowering Luz de otono was significantly higher in unapplicated $\left(0 \mathrm{~kg} \mathrm{ha}^{-1}\right)$ than other ethephon doses, but differences among the other ethephon applications were not significant (Table 3). However, value of first podding height of Histal cultivar obtained from 0 and $500 \mathrm{~g} \mathrm{ha}^{-1}$ ethephon applications was more than other applications.

Genotypic differences for branches per plant were not significant in both of the years and combined years (Table 2). However, branches per plant was significantly affected by ethephon doses in the second year and the combined years, but not in the first experimental year. The highest branches per plant was recorded in the application of 1000 and $1500 \mathrm{~g} \mathrm{ha}^{-1}$ while the lowest one was found in the control application $(0 \mathrm{~g}$ $\left.\mathrm{ha}^{-1}\right)$ in the second year and the combined years. Branches per plant was significantly affected by years. It increased due to low rainfall in the second year (3.46) compared to the first year (2.65). Thus, previous studies recorded that branches per plant may be affected by rainfall and ecological conditions (Pekşen et al., 2006; Etemadi et al., 2018). On the other hand, interaction between cultivar and ethephon application was significant for branches per plant in the combined years (Table 3 ). Branches per plant in Histal were more than Luz de otono in the high ethephon doses. Hayashi et al. (2001) reported that ethephon can be used to increase branching some crops. Field et al. (1989) reported that paclobutrazol slightly increased branches per plant in field bean. Thus, it can be said that the effect of PGRs may vary according to the species. 
Table 4. The effects of cultivars and ethephon applications on pods per plant, seeds per plant, seed weight per plant in the faba bean

\begin{tabular}{|c|c|c|c|c|c|c|c|c|c|}
\hline \multirow{2}{*}{ Treatments } & \multicolumn{3}{|c|}{ Pods/plant } & \multicolumn{3}{|c|}{ Seeds/plant } & \multicolumn{3}{|c|}{ Seed weight/plant(g) } \\
\hline & $2019 / 20$ & $2020 / 21$ & Mean & $2019 / 20$ & $2020 / 21$ & Mean & $2019 / 20$ & $2020 / 21$ & Mean \\
\hline \multicolumn{10}{|c|}{ Cultivar } \\
\hline Luz de otono & $6.54^{\mathrm{a}}$ & 4.72 & $5.63^{\mathrm{a}}$ & $22.9^{\mathrm{a}}$ & 17.3 & $20.1^{\mathrm{a}}$ & $23.9^{\mathrm{b}}$ & 17.3 & 20.4 \\
\hline Histal & $4.32^{\mathrm{b}}$ & 3.28 & $3.80^{\mathrm{b}}$ & $18.1^{\mathrm{b}}$ & 13.9 & $15.9^{\mathrm{b}}$ & $28.7^{\mathrm{a}}$ & 15.1 & 21.9 \\
\hline p.(cultivar) & $0.0038^{* * *}$ & N.S. & $0.0011^{* *}$ & 0.0272 & N.S. & $0.0137^{*}$ & $0.0072^{* *}$ & N.S. & N.S. \\
\hline \multicolumn{10}{|c|}{ Doses $\mathrm{g} \mathrm{ha}^{-1}$} \\
\hline 0 & 5.67 & $3.40^{\mathrm{b}}$ & 4.53 & 21.2 & $13.6^{\mathrm{b}}$ & 17.4 & 29.3 & 17.2 & 23.2 \\
\hline 500 & 5.60 & $3.50^{\mathrm{b}}$ & 4.55 & 21.0 & $13.4^{\mathrm{b}}$ & 17.2 & 28.4 & 14.8 & 21.6 \\
\hline 1000 & 5.03 & $4.35^{\mathrm{ab}}$ & 4.69 & 19.8 & $17.3^{\mathrm{ab}}$ & 18.5 & 22.8 & 16.2 & 19.5 \\
\hline 1500 & 5.42 & $4.75^{\mathrm{a}}$ & 5.08 & 19.9 & $18.1^{\mathrm{a}}$ & 19.0 & 23.8 & 16.8 & 20.3 \\
\hline LSD $\% 5$ & N.S. & 1.04 & N.S. & N.S. & 3.85 & N.S. & N.S. & N.S. & N.S. \\
\hline Mean & $5.43^{\mathrm{a}}$ & $4.00^{\mathrm{b}}$ & 4.72 & $20.5^{\mathrm{a}}$ & $15.6^{\mathrm{b}}$ & 18.0 & $26.1^{\mathrm{a}}$ & $16.2^{\mathrm{b}}$ & 21.1 \\
\hline p.(year) & & & $0.0027^{* *}$ & & & $0.0077^{* * *}$ & & & $0.0001^{* * *}$ \\
\hline $\mathrm{CV} \%$ & 15.6 & 20.0 & 17.8 & 16.2 & 19.5 & 17.7 & 21.8 & 20.0 & 22.0 \\
\hline
\end{tabular}

Table 5. The effects of cultivars and ethephon applications on 100-seed weight $(\mathrm{g})$ and seed yield $\left(\mathrm{kg} \mathrm{ha}^{-1}\right)$ in the faba bean

\begin{tabular}{|c|c|c|c|c|c|c|}
\hline \multirow{2}{*}{ Treatments } & \multicolumn{3}{|c|}{ 100-Seed Weight $(\mathrm{g})$} & \multicolumn{3}{|c|}{ Seed Yield $\left(\mathrm{kg} \mathrm{ha}^{-1}\right)$} \\
\hline & $2019 / 20$ & $2020 / 21$ & Mean & $2019 / 20$ & $2020 / 21$ & Mean \\
\hline \multicolumn{7}{|c|}{ Cultivar } \\
\hline Luz de otono & $125.0^{\mathrm{b}}$ & 115.6 & 120.3 & $2573^{b}$ & 1773 & $2173^{b}$ \\
\hline Histal & $165.5^{\mathrm{a}}$ & 120.0 & 142.6 & $4137^{\mathrm{a}}$ & 1910 & $3023^{\mathrm{a}}$ \\
\hline p.(cultivar) & $0.0001^{* *}$ & N.S. & $0.0001^{* *}$ & $0.0385^{*}$ & N.S. & 0.0068 \\
\hline \multicolumn{7}{|c|}{ Doses $\mathrm{g} \mathrm{ha}^{-1}$} \\
\hline 0 & $153.4^{\mathrm{a}}$ & $130.3^{\mathrm{a}}$ & $141.9^{\mathrm{a}}$ & $4491^{\mathrm{a}}$ & $2286^{\mathrm{a}}$ & $3388^{\mathrm{a}}$ \\
\hline 500 & $149.8^{\mathrm{a}}$ & $121.8^{\mathrm{b}}$ & $135.8^{\mathrm{b}}$ & $3796^{\mathrm{b}}$ & $1851^{\mathrm{b}}$ & $2823^{b}$ \\
\hline 1000 & $144.7^{\mathrm{b}}$ & $111.2^{\mathrm{c}}$ & $127.9^{\mathrm{c}}$ & $3165^{\mathrm{c}}$ & $1635^{\mathrm{b}}$ & $2399^{c}$ \\
\hline 1500 & $133.1^{\mathrm{c}}$ & $107.1^{\mathrm{c}}$ & $120.1^{\mathrm{d}}$ & $1970^{\mathrm{d}}$ & $1594^{\mathrm{b}}$ & $1782^{\mathrm{d}}$ \\
\hline LSD $\% 5$ & 4.61 & 4.80 & 3.15 & 570 & 304 & 306 \\
\hline Mean & $145.2^{\mathrm{a}}$ & $117.6^{\mathrm{b}}$ & 131.4 & $3355^{\mathrm{a}}$ & $1841^{\mathrm{b}}$ & 2598 \\
\hline p.(year) & & & $0.0000 * *$ & & & $0.0008 * *$ \\
\hline CV \% & 2.52 & 3.24 & 2.85 & 13.5 & 13.1 & 13.9 \\
\hline
\end{tabular}

$\mathrm{P} \leq 0.05^{*} ; \mathrm{P} \leq 0.01^{* *}$

The effects of cultivars and ethephon applications on pods per plant, seeds per plant and seed weight per plant of faba bean are given in Table 4.

Number of pods per plant in early maturing Luz de otona was significantly higher than late maturing Histal in the first year and the combined year, but not in the second year (Table 4). Pods per plant varied between 3.80-5.63 in mean of the year. Similarly to our findings, Etamadi et al. (2018) reported that early maturing varieties have high pods per plant. Musallam et al. (2004) releaved that pods per plant was 5.5 pod plant $^{-1}$ under rainfed conditions. Alan and Geren (2006) reported that pods per plant varied from 9.8 to 13.8 pod plant $^{-1}$. Significant differences for pods per plant were not observed among the ethephon applications in the first year and mean of the years (Table 4). However, there are significant differences among the ethephon applications only in the second year and pods per plant increased by increasing ethephon doses due to increasing branches per plant. Hence, differences between 0 and 500 $\mathrm{g} \mathrm{ha}^{-1}$ doses were not significant. The highest pods per plant was found in $1500 \mathrm{~g} \mathrm{ha}^{-1}$ (4.75) ethephon application while the lowest one was obtained from control application (3.40). Previous studies reported that the number of pods per plant reduced by ethephon application in faba bean (Ngatia et al., 2003), but it increased in kidney beans
(Sulistyono, 2000). Field et al. (1989) reported that applications of PGRs didn't affect on pods per plant in lentil, but paclobutrozol applicants increased pods per plant in faba bean. Pods per plant in 2021 (4.00) significantly decreased as compared with 2020 (5.43). These reason may be lower rainfall and higher temperature in flowering period of 2021. Similar opinions were reported in faba bean by Abdelmula and Abuanja, (2007), Etamadi et al. (2018) and Alharbi and Adhikari (2020).

The effects of cultivars and ethephon applications on seeds per plant of faba bean are given in Table 4 . The effect of cultivar on seeds per plant was significant in 2019/2020 and mean of years, but not in 2020/2021 (Table 4). Seeds per plant was significantly greater in Luz de otono with 20.1 than Histal with 15.9 in the mean of the years. Ethephon applications affected grains per plant in 2020/2021, but not in 2019/2020 and combined years. Seeds per plant increased with increasing ethephon doses as in pods per plant in the only 2020/2021. The highest seeds per plant was obtained from ethephon application of $1500 \mathrm{~g} \mathrm{ha}^{-1}$ with 18.1 followed by $1000 \mathrm{~g} \mathrm{ha}^{-1}$ doses with 17.3 in 2020/2021. Seeds per plant was significantly higher in 2020 (20.5) than 2021 (15.6) depend on low rainfall and high temperature at generative stage of plant as in pods per plant. 
Seed weight per plant was significantly affected by cultivars in 2019/2020 but not in 2020/2021 and the combined year (Table 4). Seeds weight per plant was greater in Histal (28.7 g) than Luzde otona (23.9 g) in the first year. Differences among the ethephon doses was no significant for seed weight per plant in both of the year and combined year. Seed weight varied from 19.5-23.2 $\mathrm{g}$ for the different ethophon doses in mean of the years. The seed weight per plant was statiscially higher in 2020 due to pods per plant, seeds per plant than 2021 where low rainfed and high temperature in seed formation stage of plant. The seed weight per plant was $26.1 \mathrm{~g}$ in 2019/2020 and $16.2 \mathrm{~g}$ in 2020/2021. Musallam (2004) noted that faba bean is very susceptible to drought at pod devolopment stage of plant growth.

The effects of cultivars and ethephon applications on 100- seed weight and seed yield of faba bean are given in Table 5.

Differences among the cultivars were significant for 100-grain in the 2020, but not in 2021 and the mean of year (Table 5). 100-grain weight of Histal (142.6 g) was significantly higher as compared with Luz de otono (120.3 $\mathrm{g}$ ) in the mean of the year. Late maturing Histal had higher 100-grain weight despite its lower pods per plant and seeds per plant. Seed size increased when number of pod decreased in faba bean was reported by Sözen and Karadavut (2016) and Alan and Geren (2006). Kambal et al. (1969) who that there are negative correlation between seed weight and pod number, seeds per pod in faba bean. 100 -seed weight was significantly affected by ethephon doses in both of the years and mean of the years and it decreased with the increasing ethephon doses. The highest 100 -seed weight was obtained from $0 \mathrm{~g} \mathrm{ha}^{-1}$ doses with $141.9 \mathrm{~g}$, while the lowest one was in $1500 \mathrm{~g} \mathrm{ha}^{-1}$ with 120.1 $\mathrm{g}$ in the mean of the years. Similar result was found by Güler (2009) who indicated that increasing ethephon doses generally caused to decreasing 100 weight in chickpea. 100 -seed weight was significantly higher in the first year (145.2 g) compared to the second year (117.6 g) where low rainfed and high temperature as in other generative traits.

The seed yield was significantly affected by cultivars in 2020 and the mean of the years, but not in 2021 (Table 5). The seed yield was significantly greater in later maturing Histal (3023 kg ha-1) than early maturing Luz de otono $\left(2173 \mathrm{~kg} \mathrm{ha}^{-1}\right)$ in the second year. 100- seeds weight of Histal was also higher than Luz de otono. Similar findings were recorded by Sözen and Karadavut (2016) who found that genotypes with high 100-seed weight have higher seed yield infaba bean. Musallam et al. (2004) also reported that positive correlation was found between seed yield and 100 seed weight.

Differences among the ethephon doses was significant for seed yield and the maximum seed yield was produced at control application $\left(0 \mathrm{~g} \mathrm{ha}^{-1}\right)$, while the lowest one was determined in level of $1500 \mathrm{~g} \mathrm{ha}^{-1}$ in both of the years and mean of the years. Increasing ethephon applications also reduced seed yield. Seed yield varied from 1782 to 3388 $\mathrm{kg} \mathrm{ha}^{-1}$ in the mean of the years. Hence, differences among the ethephon application except for control doses was not significant only in the second year. Güler (2009) reported that highest grain yield was obtained from ethephon application of $450 \mathrm{~g} / \mathrm{ha}$, but higher doses decreased grain yield in chickpea. Previous studies reported that seed yield was not positively affected by ethephon or some plant growth applications in faba bean (Walela et al., 2016), lentil (Turk et al., 2003), bean (Ngatia et al., 2003). On the other hand paclobutrazol increased seed yield and yield components in field bean (Vicia faba), but paclobutrazol and triapenthenol did not affect seed yield in lens (Field et al.,1989). Some studies exhibited that effect of PGR on grain yield may varied according to plant species, application time and doses of PGR, environment and physiological conditions (Walela et al. 2016; Field et al. 1989). Seed yield was higher in 2019/2020 (3355 kg ha-1) than 2020/2021 (1841 kg ha-1) where low rainfed and high temperature at the generative growth as in yield compenents. Similarly to our results, Abdelmula and Abuanja (2007) reported that heath stress during floral development decreased the seed yield in faba bean. Walela et al. (2016) indicated that seed yield was positively affected by cool and wet spring conditions during podfilling in faba bean. Similarly to our study, Ton et al (2021) reported that seed yield in local genotypes varied from $2320 \mathrm{~kg} \mathrm{ha}^{-1}$ to $3130 \mathrm{~kg} \mathrm{ha}^{-1}$ in the Mediterranean climate conditions.

\section{Conclusions}

Early maturing Luz de otono had higher pods per plant, grains per plant, but lower plant height, first podding height, 100- seed weight and seed yield than late maturing Histal in the mean of the years. There were no significant differences among the cultivars for branches per plant. As mean of the years, plant height, first podding height, 100seed weight and seed yield significantly decreased with increasing ethephon doses, but branches per plant increased. However, pods per plant, seeds per plant and seed weight per plant were not affected by ethephon applications. The maximum seed yield was produced by control application $\left(0 \mathrm{~g} \mathrm{ha}^{-1}\right)$, while the lowest one was determined in ethephon level of $1500 \mathrm{~g} \mathrm{ha}^{-1}$ in both of the year, but differences among the ethephon applications except for control does were not significant only in the second year. Interaction of cultivar and ethephon application was significant for branches per plant and first podding height in the mean of the years, but not other traits. Seed yield was higher in the first year than the second year where low rainfed and high temperature.

As a results, ethephon applications at inititation of flower were not useful for seed production of faba bean. However, it will be suitable that other experiments can be conducted with lower application doses and time to reveal effect of ethephon on the faba bean.

\section{References}

Abdelmula AA, Abuanja IK. 2007. Gemotypic responses, yield stability, and association between characters among some of Sudanese faba bean (Vicia faba L.) genotypes under heat stress. Proceeding of the Conference on International Agricultural Research for Development; Witzenhausen, Germany. 9-11 October, 2007. pp.1-7.

Alan Ö, Geren H. 2006. Ödemiş-İzmir koşullarında yetiştirilen bazı bakla (Vicia faba var. major) çeşitlerinin tohum verimi ve diğer bazı özellikleri üzerinde bir araştırma. Ege Üniversitesi Ziraat Fakültesi Dergisi, 43(1): 13-20. 
Alharbi NH, Adhikari KN. 2020. Factors of yield determination in faba bean (Vicia faba). Crop and Pasture Science, 71(4): 305-321.

Beşer E, Adak MS. 1999. Effect of different dose and application time of cycocel on yield and yield components in faba bean (Vicia faba L.). Tarla Bitkileri Merkez Araştırma Enstitüsü Dergisi, 8(1-2): 100-109.

Bora R, Sarma C. 2006. Effect of gibberellic acid and cycocel on growth, yield and protein content of pea. Asian Journal of Plant Sciences. 5: 324-330.

Effendi H, Hill G, Field R. (1989). The effect of plant population and growth regulators on growth and yield of lentil (Lens culinaris Medik.) $c v$. Olympic. Paper presented at the Proceedings of the Agronomy Society of New Zealand, 19: 25-34

El-Beltagy A, Hewett E, Hall M. 1976. Effect of Ethephon (2Chioroethyl Phosphonic Acid) on Endogenous Levels of Auxins, Inhibitors and Cytokinins in Relation to Senescence and Abscission in Vicia faba L. Journal of Horticultural Science, 51(4): 451-465.

Etemadi F, Hashemi M, Zandvakili O, Mangan FX. 2018. Phenology, yield and growth pattern of faba bean varieties. International Journal of Plant Production, 12(4): 243-250.

Field RJ, Hill GD, Attiya H J, Effendi H. 1991. Plant Growth Regulators and Grain Legumes. In: Hill GD, Savage GP (editors). Proceedings of Grain Legume Symposium and Workshop, 11-12 December 1989, Agronomy Society of New Zealand Special Publication 7. pp. 51-57.

Güler M. 2009. Ethephon Dozları ve Uygulama Zamanlarının Nohut (Cicer arietinum L.)'ta Verim ve Verim Öğelerine Etkileri. Tarım Bilimleri Dergisi, 15(4): 301-309.

Hayashi T, Heins RD, Cameron AC, Carlson WH. 2001. Ethephon influences flowering, height, and branching of several herbaceous perennials. Scientia Horticulturae, 91(34): 305-324. doi:Doi 10.1016/S0304-4238(01)00225-4

Kambal A. 1969. Components of yield in field beans, Vicia faba L. The Journal of Agricultural Science, 72(3): 359-363.

Kumar B. 2021. Plant bio-regulators for enhancing grain yield and quality of legumes: a review. Agricultural Reviews, 42(2): 175-182

Kumlay AM, Eryiğit T. 2011. Bitkilerde büyüme ve gelişmeyi düzenleyici maddeler: bitki hormonları. Journal of the Institute of Science and Technology, 1(2): 47-56.

Musallam IW, Al-Karaki G, Ereifej K, Al-Tawaha AR. 2004. Yield and yield components of faba bean genotypes under rainfed and irrigation conditions. Asian Journal of Plant Sciences, 3(4): 439-448.
Ngatia M, Shibairo S, Emongor V, Kimenju J. 2003. Effects of ethephon on the growth, yield and yield components of beans (Phaseolus vulgaris L.). Journal of Agriculture, Science and Technology, 5(1).

Pekşen A, Pekşen E, Artık C. 2006. Bazı Bakla (Vicia faba L.) Populasyonlarinin Bitkisel Özellikleri ve Taze Bakla Verimlerinin Belirlenmesi. Anadolu Tarım Bilimleri Dergisi, 21(2): 225-230.

Sheelamary S, Shivani 2015. Genetic variabiliy, heritability, and correlation of faba bean (Vicia faba L.). International Journal of Advanced Technology in Enginering and Science, 3: 4851.

Sözen Ö, Karadavut U. 2016. Determination of morphological and phenological properties of faba beans grown in eastern Mediterranean region of Turkey. Journal of Central Research Institute for Field Crops, 25(2): 209-217.

Spitzer T, Matusinsky P, Klemova Z, Kazda J. 2011. Management of sunflower stand height using growth regulators. Plant Soil and Environment, 57(8): 357-363. doi:10.17221/75/2011-Pse

Spitzer T, Misa P, Bilovsky J, Kazda J. 2015. Management of Maize Stand Height using Growth Regulators. Plant Protection Science, 51(4): 223-230. doi:10.17221/105/2014Pps

Sulistyono B. 2000. Effect of pruning and Ethephon application on the performance of kidney beans. Edisi khusus Balitkabi (Indonesia), (16): 477-482.

Ton A, Karaköy T, Anlarsal AE, Türkeri M. 2021 Genetic diversity for agro-morphological characters and nutritional compositions of some local faba bean (Vicia faba L.) genotypes. Turkish Journal Agriculture and Forestry, 45: 301-312.

Turk M, Tawaha A, El-Shatnawi M. 2003. Response of lentil (Lens culinaris Medik) to plant density, sowing date, phosphorus fertilization and ethephon application in the absence of moisture stress. Journal of Agronomy and Crop Science, 189(1): 1-6.

Verma US, Bahadur R, Singh MP. 2018. Effect of PGR on different stages of chick pea (Cicer arietinum L.). Journal of Pharmacognosy and Phytochemistry, 7(5): 3358-3360.

Walela C, Paul J, Pearce A, Ware A, Brand J, McMurray L. 2016. Faba bean agronomy and canopy management. Hart Trial Results 2016,25-30, https://www.hartfieldsite.org.au/media/ 2016\%20Trial\%20Results/Hart_Trial_Results_2016_Faba_ bean_agronomy_and_canopy_management.pdf 